\title{
The Prospect for Administrative Tribunals
}

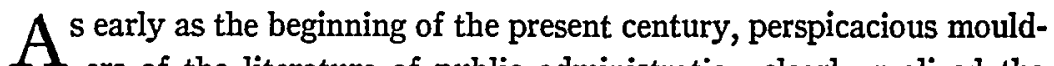
$A$ ers of the literature of public administration clearly realized the commanding rôle that administrative tribunals had come to play in administrative organization. "Of the changes that have taken place in the structure and function of the State government during the century," writes Francis $\mathrm{H}$. White, "none seenis more striking or more suggestive than the growth of this fourth department of governnient-the commission system." Just as challenging is the assertion of Leonard $\mathrm{H}$. Blue to the effect that "the chief distinguishing characteristic of modern state admimistration" is government by boards and commissions. ${ }^{2}$

Both of the above-nentioned observers believed that the commission vogue was one that could not last. Even those tribunals that were created for investigatory and judicial functions were thought to be a temporary phase in an unmistakable development toward an almost complete administrative integration. Present-day methods of administration through a commission are neither economical, efficient nor responsible, concluded Blue. "It seems hardly possible," argues White, "that the present system of almost independent commissions can be permanent. They fail to work in harmony, to cooperate, to give each other the benefit of experience that might be helpful. In the absence of a central control, there is no way to coordinate the duties of the several boards. The present seems to be a transitional stage, arising from the gradual assumption, by the State, of new duties without an adequate realization of all that is involved, and without any general plan."3 The same sort of thing was said by contemporary observers of federal and municipal commissions.

In so far as these writers prophesied the substitution of the single commissioner for the board organization, the consistency of the change has provided strong evidence of the correctness of their view. But not so with respect of administrative tribunals which possess deliberative and judicial characteristics; their nuniber and variety have increased so much in the last thirty years that ours may be designated appropriately "government by commissions"

1 White, The Growth and Future of State Boards and Commissions (1903) 18 PoL. Scr. QUART. 631, 646.

2 These he divides into investigatory, judicial, and executive. Blue, Recent Tendencies in State Administration (1901) 18 ANN. AMrer. ACAd. 434.

3 White, Op. cit. supra note 1 at 654 . 
It may be that this development has almost reached its peak point, and that the beginnings of fundamental changes are to be observed already.

Commissions have increased in proportion to the extension of the "business affected with a public interest" doctrine. At present there is considerable evidence to prove that dissatisfaction with regulation is leading to the substitution of outright ownership and operation by public authority. So widespread and seemingly deep-rooted is the criticism of commission regulation that if some new experiments in administrative organization were not forthcoming, it would be surprising.

New departures have appeared already. It would be rash to state that they indicate the beginning of any general change, but they do deserve to be examined with that possibility in mind. The charges that are launched against the commissions were familiar thirty years ago, but in recent months they have escaped from academic cloisters and have appeared in the center of partisan controversy. The commissions can be controlled by those whom they are supposed to regulate; they are not the champions of the consumer; they are financially burdensome; the commissioners are underpaid; the legislatures and courts withhold or restrain to the point of paralyzing any real effectiveness; and the commissions are practically irresponsible bodies. These are some of the most common indictments. ${ }^{4}$

The surest sign of potential change in commission control is the large number of state legislative investigations that have looked into the advisability of making alterations in the public utility laws. ${ }^{5}$ In only one state, Oregon, has an administrative change of far-reaching importance been effected. In at least three others, Pennsylvania, Minnesota, and Idaho, the governors have started open fights to bring about a change in the organization and powers of the public service commissions.

Oregon has abolished her Public Service Commission of three members and has created instead a single commissioner, officially known as the "Commissioner of Public Utilities of Oregon." $\mathrm{He}$ is appointed by the governor for a term of four years, shall receive an annual salary to be fixed by the governor and not to exceed $\$ 7500$, and may be removed at any time by the governor "for any cause deemed by him sufficient." To

\footnotetext{
4 An excellent survey of current criticisms is found in Mosmer, ELECTRICAL UTIIITIES, particularly chapter $I$.

5 Some of these are described in Hormell, State Legislation on Public Utilities in 1930 (1931) 25 AMr. Por. Scr. REv. 103-114. This was written before the completion of an equally interesting investigation in Pennsylvania.

6 ORE. LAWS (1931) c. 103, amending \$\$ 61-101, 61-102, 61-107, 61-245, 61-250, 61-261, 61-272 ORE. CODE (1930) and repealing §§ 61-103, 61-104, and 61-301 of said code.
} 
make the governor's power seemingly iron-clad, the act provides "Such power of removal shall be absolute, and there shall be no right of review of the same in any court whatsoever." Another salient provision states that it shall be the commissioner's duty "to represent the patrons, users of the service, and consumers of the product, of any public utility, and the public generally in all controversies respecting rates, charges, valuations, service and all matters of which he has jurisdiction, and in respect thereof it shall be his duty to make use of the jurisdiction and powers of his office to protect said patrons, users and consumers, and the public generally, from unjust and unreasonable exactions and practices and to obtain for them adequate service at fair and reasonable rates." The observations to be drawn from these references are rather obvious. The public utility commission, long considered an arm of the legislative branch, has metamorphosed into an integral branch of the executive department; tenure and even salary are determined by the executive; and the commissioner becomes the people's champion instead of the supposedly impartial court.

It would be difficult to explain all of the factors which brought about the demand for the change. The immediate incidents are rather definite however. The former Public Service Commission allowed an advance of rates to the street car company of Portland. This excited much opposition to the commission. The present governor announced in his campaign that he would abolish the public utility commission if he were elected. In the view of one reliable person with whom the writer has had correspondence, the reasons for the administrative change "are wholly political." Others, however, point out that some of the common criticisms of commission regulation have been rankling in the public consciousness for a considerable period. ${ }^{\mathrm{s}}$

Governors Pinchot, Olson, and Ross, like Governor Meier of Oregon,

7 ORE. LAws (1931) c. $103 \S 5$. This change has been referred to in Betters, The Case for and against the One-man Utility Commission (1931) 8 PUB. UTII. ForTn. 208.

${ }^{8} \mathrm{By}$ some Governor Meier's victory is construed as an almost single-handed triumph for the Portland Journal, the incumbent's chief journalistic support. In a letter to the writer, Mr. Marshall N. Dana, Associate Editor of the Portland Journal, states as follows, "Primarily the creation of a one-man commission was due to a desire to secure a more accurate balance between placed responsibility and authority. The old public utilities commission had fallen under the suspicion that it was more the commission of the utilities than of the public, and I am sure you, yourself, know the adroit influence of mediocre men in public office by the plausible and superior minds employed by the utilities. This may occur, of course, where there is no overt subversion nor the more crude subsidy." Prior to the passage of the bill a defense of the former commission was written by W. C. McCulloch. McCulloch, Is the Abolition of the Public Service Commission of Oregon Necessary or Desirable? (1930) 9 ORE. L. REv. 437. 
have been outspoken in their defense of the consumer's interests, as well as in their advocacy of an overhauling of the commission machinery. In each case the governor seeks more power of direction, less legislative restriction. ${ }^{9}$

The proposal of a Fair Rates Board for Pennsylvania arose from Governor Pinchot's pronounced views on the power issue ${ }^{10}$ supplemented by the results of senate and house investigations. ${ }^{11}$ Declaring the Public Service Commission "negligent in its duties, indifferent in its stewardship and a menace to proper utility regulation," the house utility investigating committee urged that all members of the commission "be immediately removed from office."12 From the administrative standpoint the principal innovations in Governor Pinchot's Fair Rate Board would be the popular election of seven members from as many zones into which the state would be divided, and the power to remove commissioners by the governor. ${ }^{13}$ The board would be "the defender of the people against high rates and poor service." The senate refused to concur in the house amendments to the Howell Bill, giving the governor power to remove members of the Public Service Commission at pleasure, ${ }^{14}$ and the other proposals in the governor's plan remain to be acted upon.

Governor Ross of Idaho proposed in lis message of 1931 the reduction of the Public Utilities Commission to one member and a material increase in his salary as a method of strengthening the regulation of public utilities. This plan has received no action. Finally, Governor Olson of Minnesota advocated in his 1931 message, among other suggestions relating to public . utilities, the appointment of an interim commission for the purpose of proposing a plan for the better regulation of rates.

Are the single commissioner, the popular election, or the removal by the governor likely to produce any better results than the customary system of plural membership, appointment, and security of tenure? The prospect for administrative tribunals may depend, to a considerable extent, upon the answer provided by these experiments. In behalf of the new departures, there may be more protection of consumer interest,

${ }^{9} \mathrm{H}$. C. Spurr has attempted an analysis of the several gubernatorial positions in Spurr, What the New Governors Think of State Regulation (1931) 7 PUB. UT⿰. FORTN. 390.

10 In his inaugural address of January 20, 1931, Governor Pinchot said in part, "I will use the full power of my office to abolish the Public Service Commission. It is the catspaw of the corporations, unfaithful to the people, and worse than useless."

11 The report of the house committee, which charged the commission with gross misfeasance and nonfeasance, will appear in the appendix to the Legislative Journal of 1931. The senate report, made under resolution of the senate of February 10, 1931, is available. The results are summarized in Bauer, Pennsylvania Investigates Public Utility Regulation (1931) 20 NaT. Mun. Rev. 372.

12 NEW YORK TAIEs, May 26, 1931. 3:5.

13 Ibid. March 24, 1931. 48:1.

14 Ibid. May 27, 1931. 2:3. 
if the governor leans that way; there is unquestionably greater administrative integration, and hence more responsibility to the voters; the cost of maintaining the administrative establishment unquestionably should be less; and the interested sections of the public would stand a much better chance of following the actions of one man, rather than three, five or even more. The governor's removal power would obviate inadequate judicial renedies, such as the one employed against the utility commission of Connecticut by taxpayers of that state. ${ }^{15}$

On the other hand, if executive boards were abolished and if advisory and investigatory boards were placed in their proper relation, the number of deliberative and judicial tribunals remaining would not be excessive. Their cost under present circumstances is small when compared to the value of the interests they regulate. Popular election of commissioners is contrary to the short ballot principle, the beneficial effects of which nay be seen everywhere. In the case of the single commissioner there is alnost every assurance that there will be bias for either the consumers or the investors, whereas with several nembers appointed with overlapping terms, governors of differing economic views are enabled to make new appointments. The "judicial habit of mind" is not as likely to be found in one man acting alone, as in several, sitting as a court. Furthermore, tenure of office devoid of executive interference is a necessary prerequisite to objectivity and fearlessness. ${ }^{16}$ Greater responsibility to the voters can be obtained by supplementing the appointing process by proficiency testing; by the legislature's making the law more clear; by providing greater safeguards for administrative conclusiveness concerning questions of fact; and by substantial increases in remuneration.

Soine of our commissions are truly a "model for judicial reform." The general criticism against regulation leaves the best commissions practically unscathed. The esprit de corps, the technique, the standards of fairness of the best administrative tribunals are among the finest heritages of the American political system. ${ }^{17}$ If the general average can be brought up near the level of the leading commissions, the future of administrative tribunals is assured.

UNIVERSity of CAIIFORNIA,

Marshall E. Dimock.

Los Angeles, CaLIfornia.

15 It resulted in the exceedingly interesting case of Levitt v. Attorney General (1930) 111 Conn. 634, 151 Atl. 171.

16 Professor James Hart shows this convincingly. Hart, The Bearing of Myers v. United States upon the Independence of Federal Administrative Tribunals (1929) 23 AMer. Poz. Sct. Rev. 657; Hart, Tenure of Office under the ConstiTUTION (1930).

17 Barnes, Public Utmity Controd in Massachusetts (1930) presents interesting evidence in support of this point. The Wisconsin and California Commissions would certainly be considered outstandingly successful tribunals. 